\title{
Effects of Totally Synthetic, Low Phenylalanine Diet on Adolescent Phenylketonuric Patients
}

\author{
CHARLES M. MCKEAN \\ From Brain-Behavior Research Center, Sonoma State Hospital, Eldridge, California 95431, U.S.A.
}

\begin{abstract}
McKean, C. M. (1971). Archives of Disease in Childhood, 46, 608. Effects of totally synthetic, low phenylalanine diet on adolescent phenylketonuric patients. The long-term responses of 5 adolescent phenylketonuric patients to chemically-defined, synthetic diets with normal and low phenylalanine content were determined.

The synthetic preparations were found capable of sustaining good health and rapid growth in this group of profoundly retarded, behaviourally disturbed patients over a $3 \frac{1}{2}$-year period without clinical or biochemical evidence of nutritional inadequacy. 4 of these patients who were treated for 6 months on a comparable diet, in which $80 \%$ of the phenylalanine was replaced by tyrosine, continued to show weight maintenance and height increases. There was no evidence of poor acceptability of the imbalanced diet, whether the blood phenylalanine concentrations were at phenylketonuric or treatment levels. The phenylalanine intake required to maintain blood phenylalanine concentrations of $3-5 \mathrm{mg} / 100 \mathrm{ml}$ in these 4 patients was well below normal requirements, and ranged between 6.8 and $20.1 \mathrm{mg} / \mathrm{kg}$ per day. Predictably, the phenylalanine requirement varied with individual growth rates.

All 4 treated patients had objective signs of improved central nervous system function during the six-month period on the phenylalanine-restricted diet. These electrophysiological and behavioural improvements were manifest after blood phenylalanine concentrations fell below $12 \mathrm{mg} / 100 \mathrm{ml}$ in 3 cases and below $5 \mathrm{mg} /$ $100 \mathrm{ml}$ in the fourth.
\end{abstract}

The enthusiasm that followed Bickel's first report (Bickel, Gerrard, and Hickmans, 1953) on the successful dietary treatment of phenylketonuria in 1953 has been tempered recently by an increasing awareness of the hazards implicit in such nutritional manipulation. Concern has centred around three potential hazards. The most serious of these is the possibility that rigorous dietary regimens may be seriously deficient in phenylalanine for meeting the requirements of rapid physical growth which could, in fact, impair the cerebral development of patients whom the diets are designed to protect. That this may be a valid concern is suggested by the work of Fuller and Shuman (1969) in which both overtreatment and undertreatment were associated with deteriorating intellectual performance in phenylketonuric individuals. Furthermore, there

Received 6 April 1971. has been speculation that totally synthetic diets provide inadequate amounts of certain unspecified nutrients found only in natural foodstuffs. Finally, it has been suspected that imbalanced amino acid composition may lead to poor acceptance of the dietary preparation of interfere with normal protein synthesis. Harper (1958) and others have observed a consistent depression of food intake and retarded growth in rats fed diets that are very deficient in a single amino acid. It has been suggested that 'the changed blood amino acid pattern serves as a signal that activates an appetite-regulating mechanism, while the pattern is an indirect reflection of some more subtle change, possibly at sites of protein synthesis' (Yoshida et al., 1966). Controlled observations have not been made to determine whether humans are similarly affected.

The present study will attempt to deal with the following questions. 
(1) Can a chemically-defined totally synthetic diet meet the complex nutritional demands and the overall health requirements of a rapidly growing phenylketonuric patient over a period of years?

(2) Is the same diet, when imbalanced with respect to phenylalanine, less acceptable than a balanced one?

(3) Is the imbalanced diet as efficient nutritionally in maintaining positive nitrogen balance, as reflected in stable body weight ?

(4) Do the phenylalanine requirements of these phenylketonuric patients fall within the normal range ?

(5) Is there evidence of improvement in central nervous system function on the low phenylalanine synthetic regimen in these profoundly retarded, adolescent patients ?

Previous studies have compared the effects of normal, unrestricted diets of natural food with low phenylalanine regimens which are generally quasi-synthetic. Consequently, the effect of amino acid imbalance could not be distinguished from that of other nutritional differences. In the first phase of our investigations we have made an effort to compare the growth of 5 pubertal phenylketonuric patients on natural food with that on a chemically-defined, totally synthetic diet with normal phenylalanine composition. In the latter phase, we have examined the acceptability and nutritional efficiency of the same synthetic diet with $80 \%$ of its phenylalanine replaced by tyrosine.

\section{Materials and Methods}

Subjects. Five ambulatory phenylketonuric patients (4 males and 1 female) in the metabolic ward of the Research Center at Sonoma State Hospital. These children at the outset of the study ranged from 7 to 11 years of age and from 9 to 14 years when the synthetic diet was initiated. They were essentially mute, with unobtainable IQ scores on the Wechsler or StanfordBinet batteries, but capable of following simple instructions. All represented problems in behavioural management.

\section{Dietary Regimens}

(1) Normal hospital diet. This consisted of the usual mixed institutional fare which is closely controlled nutritionally by hospital dietitians. This diet provided approximately $70-80 \mathrm{Cal} / \mathrm{kg}$ and $1.6 \mathrm{~g}$ protein/ $\mathrm{kg}$ for children ranging initially between $6-10$ years of age.

(2) Chemically-defined, synthetic diets

(A) Diet with normal phenylalanine content. The diets employed in this portion of the studies were generously donated by Vivonex Corporation, Mountain
View, California. This synthetic preparation ${ }^{\star}$ was based on a chemically-defined liquid diet, originally designed for animal experimentation (Greenstein et al., 1957) and later adapted for human use (Winitz et al., 1965). It was provided as a powder which was mixed with water. The resulting orange-flavoured liquid proved acceptable as the sole source of nutrition after a period of acclimatization of 1 to 4 weeks. Table I indicates its composition.

The caloric intake was adjusted upward until a steady weight gain was achieved in each patient-usually at about 3500-4000 calories per day. Later adjustments downward were necessary to avoid obesity while maintaining statural growth. On this empirical basis the present caloric intake which ranges between 2400 and 3000 calories per day was established over a 6-month period. The final intakes provided about $53 \mathrm{Cal} / \mathrm{kg}$ for the oldest children (17.5 years of age) and $76 \mathrm{Cal} / \mathrm{kg}$ for the youngest (12 years of age). A $50-\mathrm{kg}$ adolescent male, for example, was provided with $2700 \mathrm{ml}(2700 \mathrm{Cal})$ of the diet per day, which supplied $8.8 \mathrm{~g}$ available nitrogen in the form of L-amino acids and glycine, $610 \mathrm{~g}$ carbohydrate in the form of glucose polymer, and $2 \mathrm{~g}$ fat in the form of safflower oil.

(B) Synthetic diet with low-phenylalanine, hightyrosine content. Diet A was modified in only two ways: $80 \%$ of the L-phenylalanine was removed and replaced on an equimolar basis by L-tyrosine which kept the diet isonitrogenous and isocaloric. Thus the $50 \mathrm{~kg}$ boy, referred to above, who received $2700 \mathrm{Cal}$, found his phenylalanine intake reduced from $2 \cdot 8 \mathrm{~g} /$ day to $0.55 \mathrm{~g} /$ day while his tyrosine intake was increased from $3 \cdot 1 \mathrm{~g}$ to $5 \cdot 5 \mathrm{~g} /$ day. Because of limited supply, this diet was administered to the 4 male patients only. Dietary intake and weight were recorded daily for 6 months after the initiation of the low phenylalanine regimen.

(C) Adjusted low phenylalanine, high tyrosine diet. The phenylalanine content of Diet B was modified by replacing an appropriate amount with Diet A (to increase) or 'no phenylalanine', high tyrosine diet (to decrease). This permitted the final dietary adjustment necessary to maintain blood phenylalanine levels at $3-5 \mathrm{mg} / 100 \mathrm{ml}$.

\section{Clinical assessment}

(1) Physical examinations were performed half-yearly.

(2) Clinical chemistries which included haemoglobin and haematocrit, blood urea nitrogen, total plasma proteins and albumin, and cholesterol were obtained bimonthly over the first year and annually thereafter.

(3) Height and weight were determined on a monthly and weekly basis, respectively.

\section{Neurological assessment}

(1) Behavioural. Nursing personnel who were not aware of the specific dietary changes were asked to make informal daily behavioural reports on these 5 patients.

\footnotetext{
*Vivonex-100.
} 
TABLE I

Nutritional Analysis

\begin{tabular}{|c|c|c|c|c|}
\hline $\begin{array}{l}\text { Caloric value } \\
\text { Caloric composition }\end{array}$ & \multicolumn{4}{|c|}{$\begin{array}{l}1 \mathrm{Cal} / \mathrm{ml} \\
\text { Amino acids } 8.5 \% \text {, Fat } 0.7 \% \text {, CHO } 90.8 \%\end{array}$} \\
\hline \multicolumn{4}{|l|}{ Total Amino Acids } & $21 \cdot 1 \mathrm{~g} / 1$ \\
\hline & $\mathbf{g} / \mathbf{l}$ & & g/l. & \\
\hline \multirow[t]{2}{*}{$\begin{array}{l}\text { Essential } \\
\text { L-Isoleucine } \\
\text { L-Leucine } \\
\text { L-Lysine } \\
\text { L-Methionine } \\
\text { L-Phenylalanine } \\
\text { L-Threonine } \\
\text { L-Tryptophan } \\
\text { L-Valine }\end{array}$} & $\begin{array}{l}0 \cdot 91 \\
1 \cdot 45 \\
1 \cdot 09 \\
0 \cdot 94 \\
1 \cdot 04 \\
0 \cdot 91 \\
0 \cdot 28 \\
1 \cdot 01 \\
\end{array}$ & \multirow[t]{2}{*}{$\begin{array}{l}\text { Non-essential } \\
\text { L-Alanine } \\
\text { L-Arginine } \\
\text { L-Aspartic Acid } \\
\text { L-Glutamine } \\
\text { Glycine } \\
\text { L-Histidine } \\
\text { L-Proline } \\
\text { L-Serine } \\
\text { L-Tyrosone }\end{array}$} & $\begin{array}{l}0 \cdot 98 \\
1 \cdot 79 \\
2 \cdot 08 \\
3 \cdot 44 \\
1 \cdot 59 \\
0 \cdot 44 \\
1 \cdot 30 \\
0 \cdot 67 \\
1 \cdot 14\end{array}$ & \\
\hline & $7 \cdot 63$ & & $13 \cdot 44$ & \\
\hline \multicolumn{3}{|l|}{$\begin{array}{l}\text { Fat (safflower oil) } \\
\text { Carbohydrate (glucose polymer) }\end{array}$} & & $\begin{array}{rl}0 \cdot 7 & \mathrm{~g} / 1 \\
226 \cdot 0 & \mathrm{~g} / 1\end{array}$ \\
\hline Minerals & $8.6 \mathrm{~g} / \mathrm{l}$ & Vitamins/l. & Diet & Supplement * \\
\hline $\begin{array}{l}\text { Sodium } \\
\text { Potassium } \\
\text { Calcium } \\
\text { Magnesium } \\
\text { Manganese } \\
\text { Iron } \\
\text { Copper } \\
\text { Zinc } \\
\text { Chloride } \\
\text { Phosphate (as P) } \\
\text { Citrate } \\
\text { Acetate } \\
\text { Sulphate (as S) } \\
\text { Iodide } \\
\\
\text { Moisture } 82 \cdot 5 \%(\mathrm{~W} / \mathrm{V})\end{array}$ & $\begin{array}{c}1300 \cdot 0 \mathrm{mg} / \mathrm{l} . \\
1150 \cdot 0 \\
445 \cdot 0 \\
35 \cdot 0 \\
1 \cdot 5 \\
5 \cdot 5 \mathrm{mg} / 1 \\
1 \cdot 0 \\
0 \cdot 2 \\
2750 \cdot 0 \\
445 \cdot 0 \\
1600 \cdot 0 \\
8 \cdot 0 \\
6 \cdot 5 \\
0 \cdot 08\end{array}$ & $\begin{array}{l}\text { Vitamin A, IU } \\
\text { Vitamin } \mathrm{B}_{12}, \mu \mathrm{g} \\
\text { Vitamin } \mathrm{C}, \mathrm{mg} \\
\text { Vitamin D, IU } \\
\text { Vitamin E, IU } \\
\text { p-Aminobenzoic acid (K salt), mg } \\
\text { d-Biotin, mg } \\
\text { d-Calcium pantothenate, mg } \\
\text { Choline chloride, mg } \\
\text { Folic acid, mg } \\
\text { Inositol, mg } \\
\text { Niacinamide, mg } \\
\text { Pyridoxine HCl, mg } \\
\text { Riboflavine phosphate (Na salt), mg } \\
\text { Thiamine HCl, mg } \\
\text { Dried yeast, mg }\end{array}$ & $\begin{array}{c}2780 \\
2 \cdot 8 \\
39 \\
222 \\
11 \\
197 \\
0 \cdot 1 \\
5 \cdot 6 \\
45 \\
0 \cdot 06 \\
64 \cdot 5 \\
7 \cdot 4 \\
1 \cdot 1 \\
0 \cdot 91 \\
0 \cdot 7 \\
-\end{array}$ & $\begin{array}{l}30 \\
1 \cdot 25 \\
4 \cdot 2 \\
4 \\
50\end{array}$ \\
\hline
\end{tabular}

^A vitamin supplement was included-0.6 ml Abidec (Parke-Davis) + Vitamin B Complex.

(2) Electrophysiological. Standard electroencephalograms were obtained under postprandial conditions just before shifting to the low phenylalanine diet; then, 3 and 6 months after the diet was begun.

\section{Results and Discussion}

Physical examination. At no time was there a noteworthy change in status by physical examination except for the signs accompanying an exotic attack of appendicitis which followed the ingestion of a metal screw which subsequently lodged in the appendix of the only female patient in the study (Case 5). The stormy and baffling course resulted in a $10 \mathrm{~kg}$ weight loss before surgical intervention. Wound healing was rapid on the synthetic diet and weight was subsequently regained. Another patient (Case 1) developed painless haematuria while on the synthetic diet, which was detected on routine urinalysis and remained unexplained despite exhaustive diagnostic studies. There was no evidence of congenital malformation, infection, or bleeding tendency. The diet was never discontinued, and without treatment the haematuria disappeared after about one month and has not recurred. There were no other signs of illness.

Development of secondary sex characteristics was observed in Case 2 several months before initiating the synthetic diet (at 14 years); Case 4 demonstrated these developmental changes 2 years later (at 16 years); Case 1 developed little pubic and axillary hair until 16.5 years of age; and Case 3 showed no secondary sexual development. Case 5's menarche was in her thirteenth year, just before the start of this study.

Clinical chemistries. The haemoglobin, haematocrit, total protein, and albumin determina- 
tions represent protein constituents of blood with a relatively short half-life, and, as such, provide sensitive indices of change in the body's overall capacity to synthesize protein. Neither these metabolic indicators nor the blood urea nitrogen and cholesterol concentrations showed adverse effects from the synthetic diet, whether balanced or imbalanced with respect to phenylalanine.

Changes in weight and height. Throughout increasing weight and height values as evidence of positive nitrogen balance. Fig. 1 indicates the changes in weight and height for each of the 5 phenylketonuric subjects over a $5 \frac{1}{2}$-year period, 2 years before and $3 \frac{1}{2}$ years after the synthetic diets were imposed. The last point in each curve represents the final measurements after 6 months on the low phenylalanine diet. It will be noted
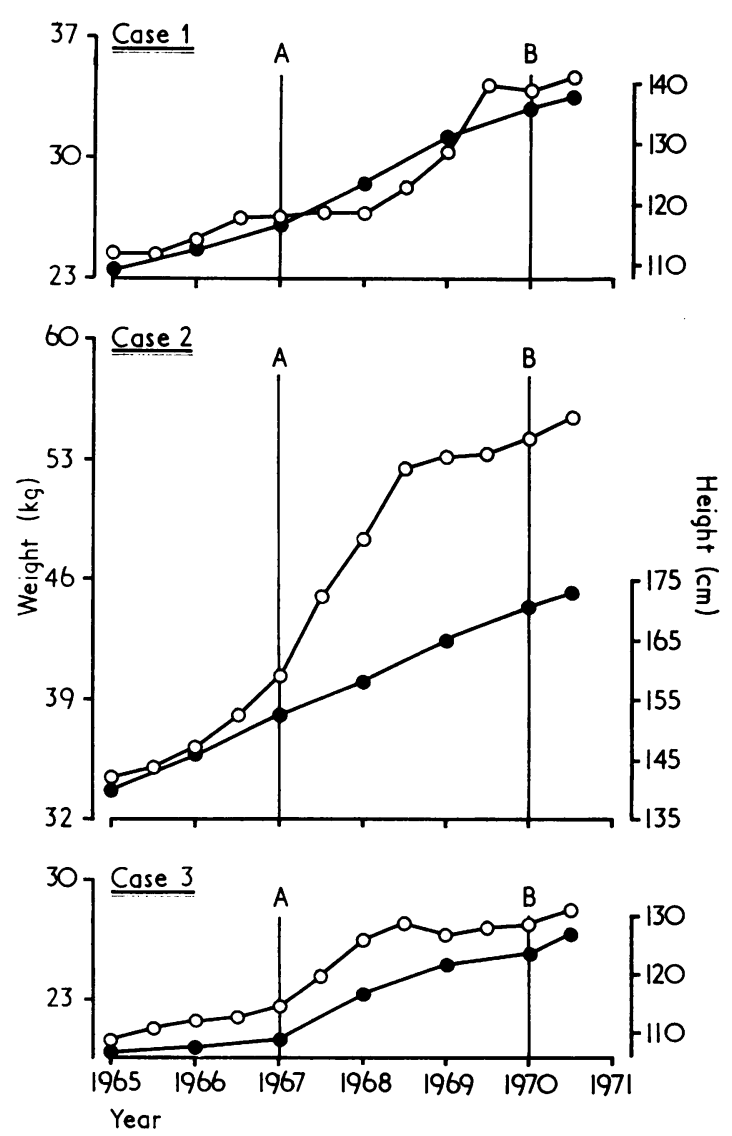
the course of this study we have used stable or

that, in general, weight was well maintained. Case 5 underwent her pubertal growth spurt before the study and was the only one of the five cases to have grown less than $18-22.5 \mathrm{~cm}$ during $3 \frac{1}{2}$ years on the synthetic regimens. Furthermore, of the 4 male cases maintained for the final 6 months on the low phenylalanine diet, only Case 4 failed to continue to gain at least $2.5 \mathrm{~cm}$ in stature.

Fig. 2 compares the yearly height increments of each child with a normal curve representing the expected acquisition of height-for-age over that same period beginning in 1965-66 and 1966-67 when the patients were on primarily natural foodstuffs. The height standards for normal school-age children were derived from the Manual for Nutrition Surveys (Interdepartmental Committee on Nutrition for National Defense, 1963). In comparison with these standard height velocities, the rates of growth on synthetic regimens were remarkably satisfactory.
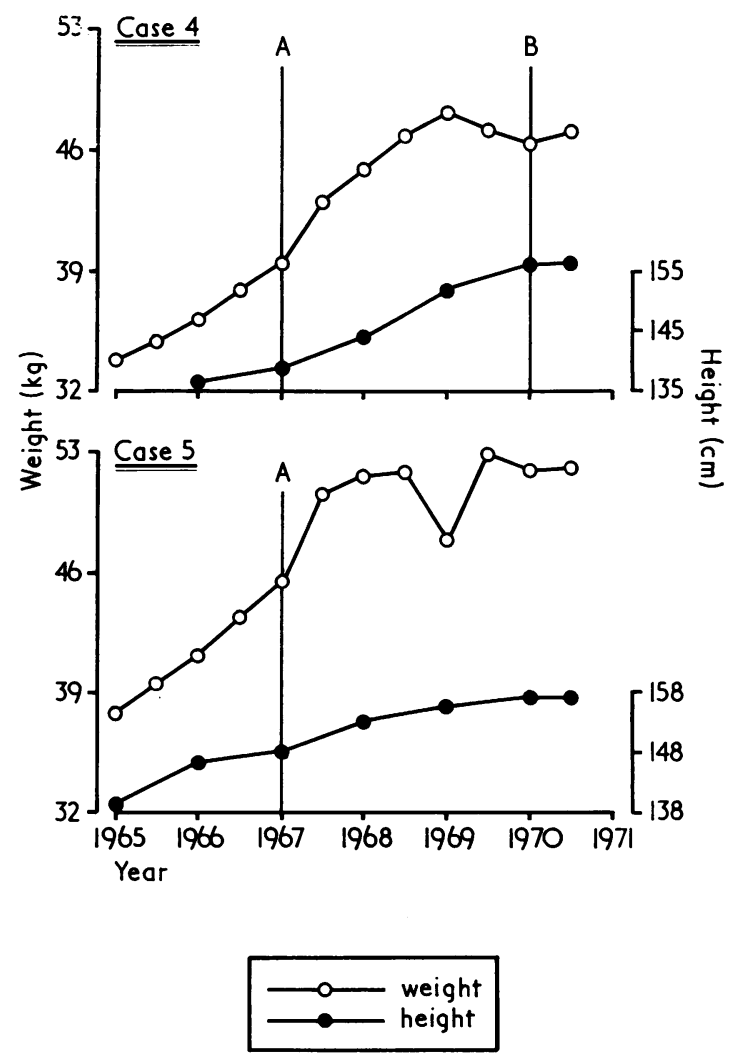

Fig. 1.-Growth on natural and synthetic diets. Synthetic Diet A (normal phenylalanine) was begun in February 1967 with all 5 cases, while Diet $B$ (low phenylalanine) was initiated 3 years later in all except one (Case 5 ) who continued for the final 6 months on Diet $A$. 

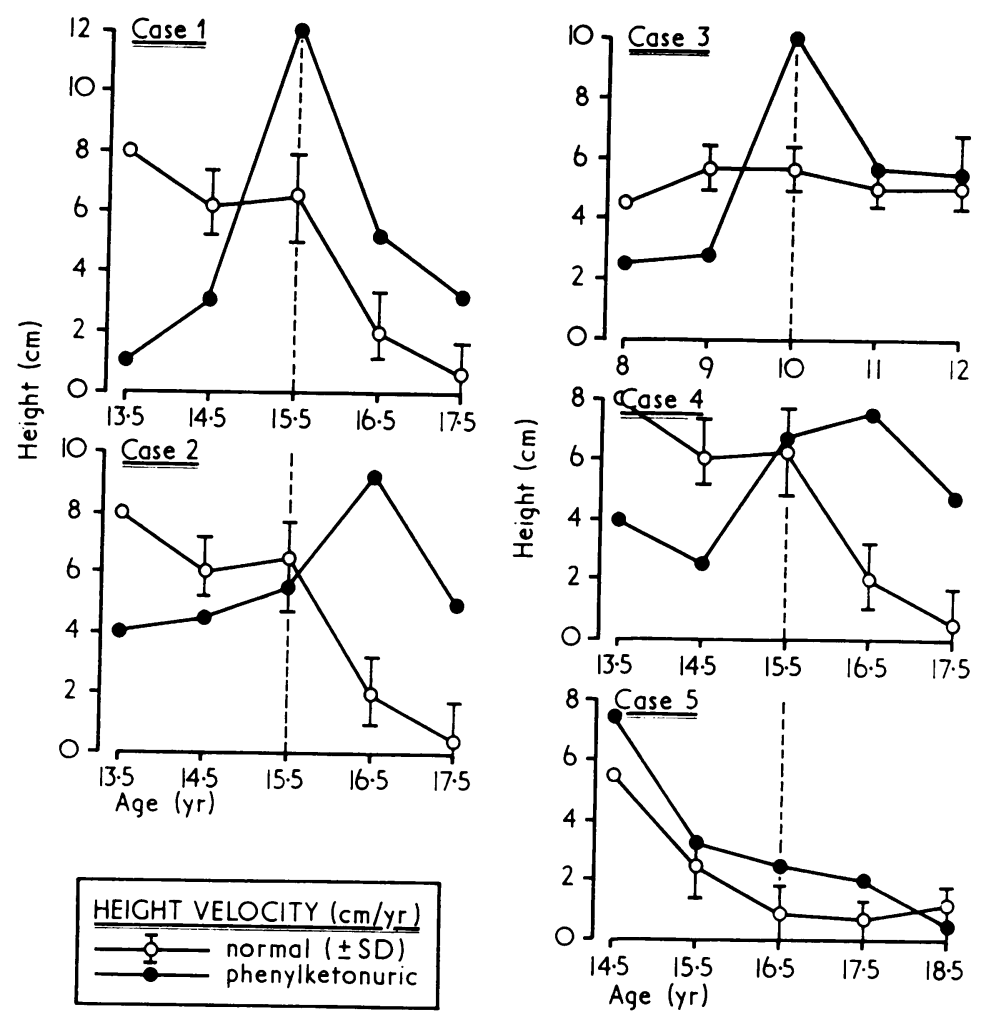

FIG. 2.-Incremental growth on synthetic diet (normal phenylalanine). Baseline data represent growth increments attained while on natural food between 1965-66 and 1966-67. Vertical line represents first year on the synthetic diet (1967-68). Normal data are presented at comparable intervals (mean height velocity $\pm 1 S D$ ).

It should be added that only 2 (Cases 2 and 5 ) of the 5 phenylketonuric patients, either before or during the period on synthetic diet, fell within 1 SD of the statural norms, despite satisfactory incremental gains during the latter years. Case 1 had had severe growth retardation from birth, and fell more than 5 SD below the norms. This is compatible with the finding of Mosier that (among 2000 retardates institutionalized in a comparable California state hospital) severe mental defect, without regard to cause, correlated with growth impairment (Mosier, Grossman, and Dingman, 1965). Other studies find, more specifically, that 35 to $50 \%$ of retardates 'without obvious organic damage' fall more than 2 SD below the norm for height (Rundle and Sylvester, 1962; Bailit and Whelan, 1967).

In this context, therefore, the relatively normal growth increments on chemical diets (noted in Fig. 2) are the more convincing.

\section{Effect of imbalanced diet}

Changes in dietary intake and weight. Table II shows the average weight for each of the 6 months before the low phenylalanine diet and for each of the 6 months after its initiation. It will be noted that the weights of each of the five patients remained constant or increased slightly-in addition to the aforementioned normal statural gain. There was no detectable change in intake after the low phenylalanine diet was started. In short, these data provide no evidence that the imbalanced character of the diet altered its acceptability or nutritional efficiency.

Phenylalanine concentrations in plasma. Fig. 3 indicates the change in blood phenylalanine levels on the low phenylalanine synthetic diet. It will be observed that the fasting blood levels of phenylalanine correlate well with the phenylalanine intake before restriction. After the $80 \%$ reduction in dietary phenylalanine, one patient (Case 2), 
TABLE II

Nutritional Response to Low Phenylalanine Diet. Average Weekly Weights 6 Months Before and After Administration of Low Phenylalanine Diet

\begin{tabular}{|c|c|c|c|c|c|c|c|c|c|c|c|c|c|}
\hline \multirow{2}{*}{$\begin{array}{l}\text { Case } \\
\text { No. }\end{array}$} & \multirow{2}{*}{$\begin{array}{c}\text { Average } \\
\text { Daily caloric } \\
\text { Intake }\end{array}$} & \multicolumn{12}{|c|}{ Months } \\
\hline & & Sept. & Oct. & Nov. & Dec. & Jan. & Feb. & March & April & May & June & July & Aug. \\
\hline $\begin{array}{l}1 \\
2 \\
3 \\
4\end{array}$ & $\begin{array}{l}2400 \\
2800 \\
2400 \\
3000\end{array}$ & $\begin{array}{l}35 \cdot 0 \\
52 \cdot 8 \\
30 \cdot 9 \\
45 \cdot 0\end{array}$ & $\begin{array}{l}35 \cdot 0 \\
52 \cdot 8 \\
30 \cdot 9 \\
45 \cdot 0\end{array}$ & $\begin{array}{l}35 \cdot 0 \\
51 \cdot 8 \\
31 \cdot 4 \\
45 \cdot 0\end{array}$ & $\begin{array}{l}35 \cdot 0 \\
52 \cdot 3 \\
30 \cdot 9 \\
45 \cdot 0\end{array}$ & $\begin{array}{l}35 \cdot 0 \\
52 \cdot 3 \\
30 \cdot 9 \\
44 \cdot 6\end{array}$ & $\begin{array}{l}\text { Kilo } \\
35 \cdot 0 \\
52 \cdot 3 \\
30 \cdot 9 \\
44 \cdot 6\end{array}$ & $\begin{array}{l}\text { ams } \\
35 \cdot 0 \\
52 \cdot 3 \\
30 \cdot 9 \\
45 \cdot 0\end{array}$ & $\begin{array}{l}35 \cdot 0 \\
52 \cdot 8 \\
30 \cdot 9 \\
44 \cdot 6\end{array}$ & $\begin{array}{l}35 \cdot 0 \\
53 \cdot 2 \\
30 \cdot 9 \\
44 \cdot 6\end{array}$ & $\begin{array}{l}34 \cdot 5 \\
54 \cdot 1 \\
31 \cdot 8 \\
44 \cdot 6\end{array}$ & $\begin{array}{l}34 \cdot 5 \\
53 \cdot 7 \\
31 \cdot 8 \\
45 \cdot 0\end{array}$ & $\begin{array}{l}34 \cdot 5 \\
53 \cdot 2 \\
32 \cdot 3 \\
45 \cdot 5\end{array}$ \\
\hline
\end{tabular}

$\star$ Average intake did not deviate more than $0.1 \%$ during any month before or during low phenylalanine regimen.

whose new phenylalanine intake of $10.6 \mathrm{mg} / \mathrm{kg}$ per day was well below that of the other patients, reached near normal blood levels in one week. Another (Case 1) who received $14 \mathrm{mg}$ phenylalanine/kg per day, did not reach a blood phenylalanine concentration of $4 \mathrm{mg} / 100 \mathrm{ml}$ for 17 days. Cases 1 and 2 were maintained between $3-5 \mathrm{mg} / 100 \mathrm{ml}$ with daily supplements of $389 \mathrm{mg}$ and $83 \mathrm{mg}$ phenylalanine which provided $20 \cdot 1 \mathrm{mg}$ and $17 \cdot 8$ $\mathrm{mg} / \mathrm{kg}$ per day, respectively.

On lower phenylalanine intakes (14 and $15 \mathrm{mg}$ phenylalanine/kg per day, respectively) Cases 3 and 4 were unable to establish blood levels below $10 \mathrm{mg} / 100 \mathrm{ml}$. After declining to $12 \mathrm{mg} / 100 \mathrm{ml}$ in 14 days, the phenylalanine concentration in Case 3 dropped very gradually to $10 \mathrm{mg} / 100 \mathrm{ml}$, while in the blood of Case 4 the level rose slightly from a low of $12 \mathrm{mg} / 100 \mathrm{ml}$ and equilibrated at $16 \mathrm{mg} /$ $100 \mathrm{ml}$. By further reducing the phenylalanine intake of Case 4 from $625 \mathrm{mg}$ to $312 \mathrm{mg}$ the blood phenylalanine was brought down to $4 \mathrm{mg} / 100 \mathrm{ml}$ in 2 weeks. Case 3 reached this therapeutic level when his intake was reduced from $500 \mathrm{mg}$ to 396 mg. Thus, the phenylalanine requirements for Cases 3 and 4 were only $12.8 \mathrm{mg}$ and $6.9 \mathrm{mg} / \mathrm{kg}$ per day, respectively.

A major contributor to the apprehension surrounding the administration of phenylalanine-

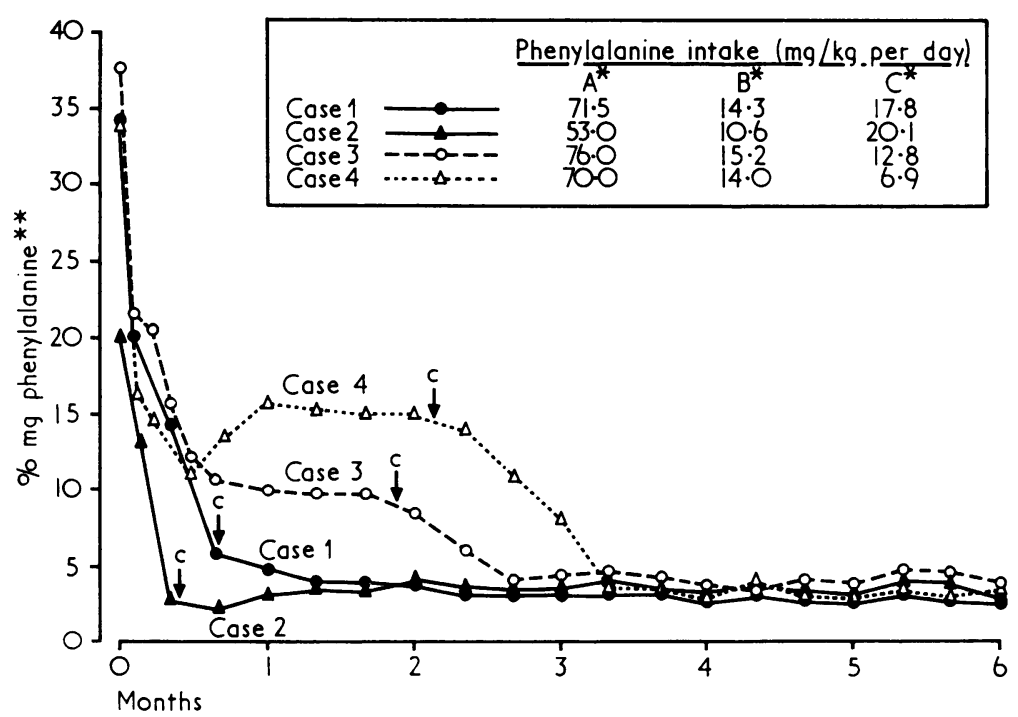

FIG. 3.-Plasma phenylalanine after phenylalanine restriction determined fluorometrically (McCaman and Robins, 1962).

${ }^{\star}$ Baseline values for plasma phenylalanine relate to Diet $A$ (with normal phenylalanine), while the remaining phenylalanine concentrations reflect responses to phenylalanine restriction. $B+C$ represent dietary intakes before and after the final adjustment of phenylalanine intake necessary to stabilize plasma concentrations at 3-5 mg/100 ml. 
restricted diets appears to be the misconceived notion that phenylketonuric children need as much phenylalanine as normal youngsters. In this study, where phenylalanine intake could be precisely monitored, it may be seen that the $6 \cdot 9-20 \cdot 1 \mathrm{mg} /$ $\mathrm{kg}$ per day requirement falls well below the 27-90 $\mathrm{mg} / \mathrm{kg}$ per day estimate for normal infants and children.

A predictable relation was found between growth and phenylalanine intake (Table III).

TABLE III

Phenylalanine Intake and Growth

\begin{tabular}{l|cc|c|c}
\hline $\begin{array}{l}\text { Case } \\
\text { No. }\end{array}$ & $\begin{array}{c}\text { Terminal } \\
\text { Age (yr) }\end{array}$ & $\begin{array}{c}\text { Weight } \\
\text { (kg) }\end{array}$ & $\begin{array}{c}\text { Phe Intake } \\
\text { (mg/kg per } \\
\text { day) }\end{array}$ & $\begin{array}{c}\text { Terminal } \\
\text { Height } \\
\text { Velocity } \\
\text { (cm/yr) }\end{array}$ \\
\hline 1 & $17 \cdot 5$ & 35 & $17 \cdot 8$ & $4 \cdot 0$ \\
2 & $17 \cdot 5$ & 53 & $20 \cdot 1$ & $5 \cdot 0$ \\
3 & 12.0 & 31 & $12 \cdot 8$ & $3 \cdot 8$ \\
4 & $17 \cdot 5$ & 45 & $6 \cdot 9$ & $2 \cdot 2$ \\
\hline
\end{tabular}

Thus, Case 2 was growing at the rate of $5 \mathrm{~cm}$ per year, and was able to maintain a blood phenylalanine level of $3.5 \mathrm{mg} / 100 \mathrm{ml}$ with an intake of $20.1 \mathrm{mg} /$ $\mathrm{kg}$ per day, while Case 4 grew only $2 \cdot 2 \mathrm{~cm}$ and did not grow at all in the final 6 months, requiring only $6.9 \mathrm{mg} / \mathrm{kg}$ per day to maintain the same blood phenylalanine level.

Change in neurological status. Anecdotal nursing records give strong evidence of behaviour improvement in Cases 1 and 4 . Case 4 had a particularly dramatic change in mood and temperament. As his blood phenylalanine concentration declined to about $12 \mathrm{mg} / 100 \mathrm{ml}$, his personality dramatically changed: he was transformed from a whining, irritable child to one who was smiling and responsive. Case 1 also showed a marked improvement in mood with a reduction in his frequent episodes of crying and irritability. This was noted after about 10 days of the low phenylalanine regimen, at which time his blood level was also $10-12 \mathrm{mg} / 100 \mathrm{ml}$. At about the same point Case 3 also had some improvement in temperament and in ability to sustain attention while at play. However, Case 2 showed no perceptible change in behaviour until the phenylalanine concentration fell below $5 \mathrm{mg} / 100 \mathrm{ml}$.

Electrophysiological change. The 3 patients with early behavioural improvement showed objective evidence of EEG improvement also, consisting primarily of readily demonstrable decreases in paroxsymal slow wave activity. This was true on both the 3- and 6-month post-treatment records.

Further evidence of electrophysiological improvement in the summated cortical responses evoked by patterned flash has been observed after plasma phenylalanine levels returned to normal. Preliminary data have been previously noted (Marcus, 1970) and will subsequently be reported in detail. The most consistent therapeutic response was significant shortening of the abnormally prolonged latency times for the visually evoked responses (VER). The decrease in conduction time was most obvious in Cases 3 and 4: they each had a steep drop in latency when blood phenylalanine concentrations fell below $12 \mathrm{mg} / 100 \mathrm{ml}$, which was also accompanied by an abrupt increase in blood serotonin and improved behaviour. Case 2, on the other hand, showed a delay in the appearance of electrophysiological and behavioural changes.

Of interest in regard to the neurological improvement are the associated changes in whole blood serotonin, which is thought to be a modulator of nervous system activity. We have noted that serotonin levels usually rise steeply as plasma phenylalanine concentrations approach $12 \mathrm{mg} / 100$ $\mathrm{ml}$ (unpublished data). Cases 3 and 4 displayed the most rapid and the highest rises among the 4 treated patients, from 150 to $320 \mathrm{ng}$ per $\mathrm{ml}$. Case 2's serotonin value $(125 \mathrm{ng} / \mathrm{ml})$ did not change significantly until the blood phenylalanine dropped below $5 \mathrm{mg} / 100 \mathrm{ml}$, at which time the serotonin concentration rose to $270 \mathrm{ng} / \mathrm{ml}$ and the VER latency decreased.

These data provide strong presumptive evidence that it is possible to maintain good nutrition and to improve central nervous system function in certain previously untreated, profoundly retarded phenylketonurics, when phenylalanine concentrations are reduced below $12 \mathrm{mg} / 100 \mathrm{ml}$ using a synthetic dietary preparation. With the help of objective tests of CNS function (such as the VER), it may be practical to identify those patients of any age who will respond to phenylalanine restriction. In such cases, it would be helpful to determine the maximum phenylalanine level that will still permit the observed neurological improvement in order to permit effective dietary planning.

The author wishes to express particular appreciation to Elizabeth Grantham, R.N., and her dedicated staff for their keen interest and careful clinical surveillance throughout the course of these studies and to the Vivonex Corporation for their provision of special dietary formulations.

These investigations supported by United States Public Health Service Research Grant No. 01823 from 
National Institute of Child Health and Human Development.

\section{REFERENCES}

Bailit, H. L., and Whelan, M. A. (1967). Some factors related to size and intelligence in an institutionalized mentally retarded population. Fournal of Pediatrics, 71, 897.

Bickel, H., Gerrard, J., and Hickmans, E. M. (1953). Influence of phenylalanine intake on phenylketonuria. Lancet, $2,812$.

Fuller, R. N., and Shuman, J. B. (1969). Phenylketonuria and intelligence: trimodal response to dietary treatment. Nature (London), 221, 639.

Greenstein, J. P., Bernbaum, S. M., Winitz, M. and Otey, M. C. (1957). Quantitative nutritional studies with water-soluble, chemically-defined diets. I. Growth, reproduction and lactation in rats. Archives of Biochemistry and Biophysics, 72, 396.

Harper, A. E. (1958). Balance and imbalance of amino acids. Annals of the New York Academy of Sciences, 69, 1025.

Interdepartmental Committee on Nutrition for National Defense (1963). Manual for Nutrition Surveys, 2nd ed. U.S. Government Printing Office, Washington, D.C.
McCaman, M. W., and Robins, E. (1962). Fluorimetric method for the determination of phenylalanine in serum. Fournal of Laboratory and Clinical Medicine, 59, 885.

Marcus, M. M. (1970). The evoked critical response: a technique for assessing development. Californian Mental Health Research Digest, 8(2), 59 .

Mosier, H. D., Jr., Grossman, H. J., and Dingman, H. F. (1965). Physical growth in mental defectives. Pediatrics, 36(3), 465, (Part II).

Rundle, A. T., and Sylvester, P. E. (1962). Endocrinological aspects of mental deficiency. III. Growth and development of young males. fournal of Mental Deficiency Research, 7, 10.

Winitz, M., Graff, J., Gallagher, N., Narkin, A., and Seedman, D. A. (1965). Evaluation of chemical diets as nutrition for man-in-space. Nature (London), 205, 741.

Yoshida, A., Leung, P. M-B., Rogers, Q. R., and Harper, A. E. (1966). Effect of amino acid imbalance on the fate of the limiting amino acid. fournal of Nutriticn, 89, 80.

Correspondence to Dr. C. M. McKean, Sonoma State Hospital, Eldridge, California 95431, U.S.A. 